\title{
Bacterial diversity and community in Qula from the Qinghai- Tibetan Plateau in China
}

\author{
Yan Zhu ${ }^{1}$, Yingying Cao ${ }^{1}$, Min Yang ${ }^{2}$, Pengchen Wen ${ }^{1}$, Lei Cao ${ }^{1}$, Jiang Ma ${ }^{1}$, Zhongmin Zhang ${ }^{1}$, \\ Weibing Zhang ${ }^{\text {Corresp. } 1}$ \\ ${ }^{1}$ College of Food Science and Technology Engineering, Gansu Agricultural University, LanZhou, Gansu, China \\ 2 College of Science, Gansu Agricultural University, Lan Zhou, China \\ Corresponding Author: Weibing Zhang \\ Email address: zzz888666@gsau.edu.cn
}

Qula is a cheese-like product usually prepared with unpasteurized yak milk under open conditions, with both endogenous and exogenous microorganisms involved in the fermentation process. In the present study, 15 Qula samples were collected from five different regions in China to investigate the diversity of microbial communities using highthroughput sequencing targeting the V3-V4 region of 16S rRNA gene. The bacterial diversity significantly differed among samples of different origins, indicating a possible effect of geography. The result also showed that microbial communities significantly differed in samples of different origin and these differences were greater at the genus than the phylum level. A total of six phyla were identified in the samples, and Firmicutes and Proteobacteria had a relative abundance $>20 \%$. A total of 73 bacterial genera were identified in the samples. Two dominant genera )Lactobacillus and Acetobacter) were common to all samples, and a total of 47 operational taxonomic units at different levels significantly differed between samples of different origin. The predicted functional genes of the bacteria present in samples also indicated differences in bacterial communities between the samples of different origin. The network analysis showed that microbial interactions between bacterial communities in Qula were very complex. This study lays a foundation for further investigations into its food ecology. 
$1 \quad$ Bacterial diversity and community in Qula from the Qinghai-

\section{Tibetan Plateau in China}

3 Yan Zhu, Yingying Cao, Min Yang, Pengchen Wen, Lei Cao,Jiang Ma, Zhongmin Zhang, Weibing

5 College of Food Science and Technology Engineering, Gansu Agricultural University, Lanzhou 730070, China 6

7 *Corresponding Author:

8 E-mail address: zzz888666@gsau.edu.cn 


\section{Abstract}

10 Qula is a cheese-like product usually prepared with unpasteurized yak milk under open conditions, with both 11 endogenous and exogenous microorganisms involved in the fermentation process. In the present study, 15

12 Qula samples were collected from five different regions in China to investigate the diversity of microbial 13 communities using high-throughput sequencing targeting the V3-V4 region of 16S rRNA gene. The bacterial 14 diversity significantly differed among samples of different origins, indicating a possible effect of geography. 15 The result also showed that microbial communities significantly differed in samples of different origin and 16 these differences were greater at the genus than the phylum level. A total of six phyla were identified in the 17 samples, and Firmicutes and Proteobacteria had a relative abundance $>20 \%$. A total of 73 bacterial genera were identified in samples. Two dominant genera (Lactobacillus and Acetobacter) were common to all samples, and a total of 47 operational taxonomic units at different levels significantly differed between samples of different origin. The predicted functional genes of the bacteria present in samples also indicated differences in bacterial communities between the samples of different origin. The network analysis showed that microbial interactions between bacterial communities in Qula were very complex. This study lays a foundation for

its

food

ecology. 


\section{INTRODUCTION}
The yak is the only bovine species adapted to the cold and harsh conditions of the Hindu Kush-Himalayan region and the Qinghai-Tibetan plateau with its altitude range of 2000-5000 m above sea level (Cui, et al., 2016). In China, there are about 14 million yak distributed in Yunnan, Xizang, Qinghai, Gansu, Sichuan, and other provinces, accounting for $95 \%$ of the world's yak population. Yak have been central to the development of the farming and pastoral communities of these areas (He, et al., 2011).

Yak produce milk with high nutritive value, which is considered a high-quality raw material for manufacturing food such as yak butter, milk powder, cheese, and fermented milk (He, et al., 2011). Qula is a traditional homemade fermented cheese-like yak milk product, which has been made and consumed in Yunnan, Xizang, Qinghai, Gansu, and Sichuan for thousands of years (Li, et al., 2010; He, et al., 2011). Due to the dispersion of yak milk, fresh yak milk is often processed to Qula on local yak farms, and can be stored for years ( $\mathrm{Li}$, et al., 2010). Qula is white or yellow grain, and contains $7-12 \%$ moisture and approximately $80 \%$ protein. Nowadays, Qula is usually collected and transported to a factory to make yak milk casein. Because

Qula is usually prepared with unpasteurized yak milk under open conditions, both endogenous and exogenous microorganisms are involved in the fermentation process. In the past several years, microbial species in Qula has been traditionally identified by conventional culture and molecular biology methods (Duan, et al., 2008; Zhang et al., 2015). However, it is obvious that these methodologies are not optimal to provide detailed information regarding the microbial communities in complex matrixes for technique limitations $(\mathrm{Li}$, et al., 2011; Ao, et al., 2012; Ding, et al., 2017).

\section{High-throughput sequencing technologies such as Illumina MiSeq sequencing are now powerful tools for}

better assessment of microbial diversity due to low cost and high read quantity and quality (Liu, et al., 2007; 
45 Caporaso, et al., 2012; Kryachko, et al., 2012; Solieri, et al., 2013; Lenchi, et al., 2013; Tago, et al., 2014).

Numerous studies have been carried out to determine microbial communities of fermented food including

Plaisentif cheese, salami, Pu-erh tea, and douchi (Polka, et al., 2015; Dalmasso, et al., 2016; Zhang, et al., 2016;

Yang, et al., 2016; Zhang, et al., 2018). However, relatively little research has addressed the microbial

community structure in traditional Qula using modern culture-independent molecular techniques, especially

Illumina MiSeq sequencing. This study's objective was to make an inventory of the diversity of microbial

communities in Qula from different regions in China using Illumina MiSeq approaches. The data generated,

particularly the differences in the distribution of particular taxonomic groups, were used to evaluate the effect

of the processing environments on the bacterial communities.

\section{MATERIALS AND METHODS}

Sample collection

Qula samples were collected in October 2016. Homemade Qula samples were purchased directly from

ice box for transportation to the laboratory for extraction of DNA.

60

61

\section{DNA extraction}

DNA was extracted from $0.2 \mathrm{~g}$ of the Qula samples using an E.Z.N.A. Soil DNA Kit D5625-01 (OMEGA, Norcross, GA, USA) according to the manufacturer's instructions. The extracted DNA was quantified using a Qubit 2.0 spectrophotometer (Invitrogen, Carlsbad, CA, USA), and the integrity of the extracted DNA from the Qula samples was confirmed by electrophoresis in a $0.8 \%$ agarose gel.

\section{Illumina MiSeq sequencing}

Next generation sequencing library preparations and Illumina MiSeq sequencing was conducted at Shanghai 
67 Personal Biotechnology Co. Ltd. (Shanghai, China). The primers 338F (ACTCCTACGGGAGGCAGCA) and 806R (GGACTACHVGGGTWTCTAAT) with barcodes were employed to amplify the bacterial 16S rRNA genes from the extracted DNA (Feng, et al., 2017). The PCR amplification was conducted using high-fidelity Trash Start Fastpfu DNA Polymerase (Trans Gen Biotech, China). The thermal cycle conditions were as follows: $5 \mathrm{~min}$ at $95^{\circ} \mathrm{C}$; followed by 25 cycles of $30 \mathrm{~s}$ at $95^{\circ} \mathrm{C}, 30 \mathrm{~s}$ at $56^{\circ} \mathrm{C}$, and $40 \mathrm{~s}$ at $72^{\circ} \mathrm{C}$; then $10 \mathrm{~min}$ at $72^{\circ} \mathrm{C}$, after which the samples were cooled at $4^{\circ} \mathrm{C}$.

\section{Processing of high-throughput sequencing data}

Amplicons were sequenced using a paired-end method by Illumina Miseq with a six cycle index read. Raw data generated from the high-throughput sequencing run were processed and analyzed following the pipelines of Mothur (V.1.31.2) and QIIME (V1.7.0) (Schlosset, et al., 2009; Caporaso, et al., 2012). Sequence reads were trimmed so that the average Phred quality score for each read was above 20. After trimming, these reads were assembled using the Flash software (V.1.2.7) (Fu, et al., 2015) and reads that could not be assembled were discarded. Chimera sequences were identified and removed using UCHIME (V.4.2) (Edgar, et al., 2011). Quality sequences were clustered into operational taxonomic units (OTUs) using a 97\% identity threshold with QIIME's uclust (Fu, et al., 2015).

The taxonomic identities of bacterial OTU representative sequences were classified with the Ribosomal Database Project (RDP) classifier with the SILVA databases (Wang, et al., 2007). This dataset is available in the SRA at the NCBI under accession number SRP128600 (https://www.ncbi.nlm.nih.gov/sra/SRP128600).

\section{Diversity and statistical analysis}

The relative abundance (\%) of individual taxa within each community was estimated by comparing the number of sequences assigned to a specific taxon to the number of total sequences obtained for that sample. 
Alpha diversity analysis, which included the Simpson, Chao1, and Shannon indices, was performed using the summary single command of the MOTHUR software (V.1.31.2, http://www.mothur.org/). One-way ANOVA followed by Bonferroni's multiple comparison post-hoc tests was used to explore variations in Chao1 richness index and Shannon index.

Unweighted UniFrac distances principal coordinates analysis (unweighted UniFrac PCoA) was performed using the R software package (v 2.15.3; https://www.r-project.org/) on the basis of the relative abundance of bacterial genera. Unweighted pair-group method with arithmetic means (UPGMA) clustering was also performed using QIIME 1.7.0 (Caporaso, et al., 2010) and displayed using $\mathrm{R}$ software (v 2.15.3; https://www.r-project.org/). The Adonis permutational multivariate analysis (Adonis/PERMANOVA) and analysis of similarities (ANOSIM) were used to assess the differences of bacterial community structure in samples.

Differentially abundant features among the different samples were identified using the linear discriminant analysis (LDA) effect size (LEfSe) pipeline (http:/huttenhower.sph.harvard.edu/galaxy/) on the OTU level (relative abundance $>1 \%$ ). Taxa with significant differential abundances were detected by the nonparametric factorial Kruskal-Wallis (KW) rank sum test. The LEfSe analysis was performed with an alpha value for the Kruskal-Wallis test of 0.05 and a threshold on the logarithmic LDA score of 2.0 (Xu, et al., 2017).

Phylogenetic investigation of communities by reconstruction of unobserved states software (PICRUSt, v1.0, http://picrust. github.io/picrust/) was used to predict metagenome functional features from 16S rRNA genes (Langille, et al., 2013; Chen, et al., 2015; Wu, et al., 2016). The threshold of Picking OTUs for use in PICRUSt is $97 \%$. Predicted functional pathways were annotated by using the Kyoto Encyclopedia of Genes and Genomes (KEGG) (Kanehisa et al., 2012; Langille et al., 2013). OTUs for which a KEGG profile could 
not be retrieved constitute the fraction of unexplained taxonomic units (FTU). The abundance of the retrieved

KEGG metabolic profiles in samples from different regions were reported as mean \pm standard error of the mean. One-way ANOVA followed by Duncan' test was used to determine significant differences between the samples and differences were considered significant when $\mathrm{p}<0.05$.

The top 50 bacterial genera in Qula samples were used for network analysis. Spearman's rank correlations between selected genera were calculated using the R package (Ihaka, et al., 1996). A valid co-occurrence was selected as a strong correlation if the Spearman's correlation coefficient $(\rho)$ was greater than 0.6 with a significance level less than 0.01 (Barberán, et al., 2012; Huang, et al., 2017). Correlation networks between genera in the samples were constructed and visualized in the Cytoscape software (v 3.2.1; http://www.cytoscape. org/) (Shannon, et al., 2003).

\section{RESULTS}

\section{Sequencing and classification}

Total DNA was extracted from the Qula samples, after which V3-V4 of the 16S rRNA gene was PCR amplified from each DNA sample. PCR products were sequenced using the paired-end method by Illumina MiSeq. After quality control, a total of 302,930 high-quality 16S r RNA gene sequences were recovered from the samples (Table 2). The average lengths of high-quality sequences were $455 \mathrm{bp}$ for the bacterial community. The high-quality sequences were grouped into 1576 OTUs at the $97 \%$ similarity level and, after removing singletons, the average number of OTUs was 105 . The samples from Qinghai had the highest diversity of bacterial communities (165 OTUs), and samples from Yunnan had the lowest (45 OTUs).

In the study, the coverage of all samples was in the range of $96.45-98.56 \%$, indicating an adequate level of sequencing to identify most diversity in the samples. The rarefaction curve for Shannon diversity indices was 
130

131

132

133

134

135

136

137

nearly parallel with the $\mathrm{x}$-axis (Figure 1) and the Shannon diversity index reached saturation, suggesting that although new phylotypes would be expected with additional sequencing, the majority of bacterial phylotypes present in Qula had been captured.

\section{Analysis of alpha diversity}

Two indices were determined (Chao1 richness index and Shannon index) to measure the alpha diversity of the microbiome in the analyzed sample (Table 2). The microbial diversity was compared, as estimated by the Shannon index, and the result showed that the bacterial diversity difference was statistically significant (P $<0.001$, Bonferroni's test) in Qula samples from different origins, indicating that geography may have impacted the bacterial diversity in the samples. The samples from Sichuan had the highest bacterial diversity (Table 2), implying more abundant bacteria compared with samples from other regions. We also found that bacterial diversity was lowest in samples from Yunnan (Table 2).

We also compared the bacterial species richness, as estimated by the Chaol richness index (Table 2). The samples from Sichuan had the highest bacterial species richness, while the bacterial species richness of the samples from Yunnan is the lowest. The bacterial species richness was significantly different $(\mathrm{P}<0.001$, Bonferroni's test) in samples from different origins except for Qula samples collected in Xizang and Sichuan $(\mathrm{P}=1.000$, Bonferroni's test $)$.

\section{Comparison of bacterial communities in samples}

We examined the compositions of bacterial communities in the samples. A total of six phyla were identified in the samples, and Firmicutes and Proteobacteria had a relative abundance $>20 \%$ (Table 3, Figure S1). The relative abundance of Firmicutes, the most abundant phylum in all samples, was in the range of 45.7-79.2\%.

Proteobacteria was the second most abundant phylum, with a relative abundance of $20.80-54.18 \%$. 
151

152

153

154

155

156

157

158

159

160

161

162

163

164

165

166

167

Actinobacteria was the third most abundant phylum in samples from Xizang and Qinghai, but its relative abundance was below $1 \%$ in other samples. The relative abundance of the other three phyla was lower than $1 \%$ and differed between samples from different regions.

A total of 73 bacterial genera were identified in the samples. The abundance of the main bacterial genera in the samples is shown in Table 3 and Figure S2. A total of 10 dominant genera were observed in all samples, all with a relative abundance exceeding 1\%. In the samples from Yunnan, Lactobacillus and Acetobacter were the dominant genera, with relative abundance of 79.12 and $17.92 \%$, respectively. Five dominant genera (Acetobacter, Lactococcus, Lactobacillus, Leuconostoc, and Enterococcus) were observed in samples from Xizang, with relative abundance in the range of 1.13-41.43\%. Among them, Acetobacter and Lactococcus were the first and second most abundant genera, representing $82.52 \%$ of the bacterial population. Nine genera (Lactococcus, Leuconostoc, Lactobacillus, Acetobacter, Streptococcus, Acinetobacter, Burkholderia, Ralstonia, and Rhodanobacter) were dominant in samples from Qinghai, with relative abundance of 23.37, 18.97, 14.48, $14.06,5.43,4.58,3.83,1.32$, and $1.20 \%$, respectively. In samples from Gansu, there were three dominant genera (Acetobacter, Lactobacillus, and Lactococcus) with 50.66, 36.81, and 7.71\%, respectively. Seven bacterial genera (Lactococcus, Pseudomonas, Leuconostoc, Lactobacillus, Acetobacter, Acinetobacter, and Streptococcus) were dominant in samples from Sichuan, with relative abundance 26.63, 23.83, 15.26, 13.15, $5.84,2.09$, and $1.25 \%$, respectively. Additionally, a total of 63 non-dominant bacterial genera were present in the samples, all with a relative abundance less than $1 \%$.

Linear discriminant analysis showed a significant difference in bacterial community compositions in Qula from different regions (Figure 2). We observed that a total of 47 OTUs (six in samples fromYunnan, 20 from Qinghai, four from Xizang, four from Gansu, and 13 from Sichuan) significantly differed between samples 
172 from different origins. Of Firmicutes, six bacterial genera significantly differed between samples; and11

173 genera of Proteobacteria differed.

174

175

176

\section{Analysis of beta diversity}

The beta diversity results of unweighted UniFrac PCoA (Figure 3) based on the relative abundance of bacterial community showed that most samples from the same location were closely grouped together except for QH1. The sample (QH1) cluster with the $\mathrm{XZ}$ samples, indicating that the microbiota in this sample (QH1) may be affected by other factors such as breed, diet, or parity. The results were much similar when comparing samples from different regions using unweighted pair-group analysis (Figure 4). The Adonis/PERMANOVA was scored with $\mathrm{P}=0.001(\mathrm{P}<0.05$, in significant level). The results of ANOSIM's statistical analysis showed that the production region was a salient factor affecting the bacterial composition of the different samples $(\mathrm{R}=0.9304, \mathrm{P}=0.001)$. A heatmap analysis (Figure 5) of the top 50 bacterial genera also indicated a significant difference in bacterial communities between samples.

Thus, we concluded that the bacterial flora in the samples was stratified by geographic region. The Qula samples used in this study were produced by similar traditional methods. Therefore, it is likely that the differences in microbial structure between samples of different origin were due to geographic location and other environmental factors.

\section{Functional genes of the bacteria present and their metabolism in Qula samples}

The PICRUSt software was used to predict the functional genes of the bacteria present in samples and their metabolic pathways. The fraction of unexplained taxonomic units (FTU) is shown in Table S1. The fraction was highest in the samples from Sichuan $(14.35 \pm 1.64 \%)$ and lowest in the samples from Yunnan $(3.46 \pm 0.29 \%)$. For the samples from other origins, the FTU was not significant ( $\mathrm{P}>0.05$, Duncan' test). 
Of the functional microbial genes in the samples, $44.17-50.37 \%$ were related to the following metabolic pathways: amino acid (AA) metabolism, carbohydrate metabolism, energy metabolism, metabolism of cofactors and vitamins, nucleotide metabolism, lipid metabolism, xenobiotics biodegradation and metabolism, enzyme families, metabolism of terpenoids and polyketides, metabolism of other AAs, glycan biosynthesis and metabolism, and biosynthesis of other secondary metabolites (Table 4). Genes involved in AA metabolism and carbohydrate metabolism predominated in samples of different origin. Genes involved in AA metabolism, Biosynthesis of Other Secondary Metabolites, Enzyme Families, Lipid Metabolism, Metabolism of Cofactors and Vitamins, Metabolism of Other Amino Acids, Metabolism of Terpenoids and Polyketides, Nucleotide Metabolism, Xenobiotics Biodegradation and Metabolism in the samples from Yunan were significantly different $(\mathrm{P}<0.001$, Duncan' test) from other origins. Genes involved in carbohydrate metabolism in samples from Sichuan were significantly different from other origins $(\mathrm{P}<0.001$, Duncan' test $)$.

Other functional genes of the bacteria in samples were related to cellular processes, environmental information processing, genetic information processing, human diseases, organismal systems, and others (Table 5). Among these, genes involved in membrane transport were dominant in samples. Genes involved in membrane transport in the samples from Yunan were significantly different $(\mathrm{P}<0.001$, Duncan' test) from other origins except for samples from Sichuan ( $\mathrm{P}>0.05$, Duncan' test).

A heatmap was plotted to estimate the similarities of the samples for the functional genes (Figure 6). Most of the samples from different origin cluster with each other except for QH1 again. The results were consistent with our previous cluster analysis results of the bacterial community.

\section{Microbial interactions in samples}

In the present study, relationships between genera in the samples were calculated using the Spearman rank 
214 correlation coefficient and visualized as a network in Cytoscape software (Figure 7). The network for microbial

215 community in samples consists of 47 nodes and 244 edges. A total of 36 bacterial genera were found to be hub

216 genera ( $\geqslant 6$ edges per node) in the network, such as Lactococcus, Lactobacillus, Leuconostoc, Acinetobacter,

217 Pseudomonas, Enterococcus, Enterobacter, Enhydrobacter, Bacillus, Chryseobacterium, Staphylococcus,

218 Janthinobacterium, Pseudomonas, Sphingomonas, and others. The network is dominantly cooperative, and the

219 ratio of cooperative vs. non-cooperative interactions is 115:7. All the non-cooperative interactions were found to be

related to the genera Lactobacillus, Acetobacter, and Gluconobacter. Lactobacillus had a negative relationship

221

with six other genera: Lactococcus, Enterococcus, Enterobacter, Erwinia, Salmonella, and Serratia.

Acetobacter was negatively associated with four other genera: Pseudomonas, Camobacterium,

Sediminibacterium, and Jeotgalicoccus. Gluconobacter was negatively related to four other genera: Bacillus,

Brevibacterium, Sediminibacterium, and Tetragenococcus. Other bacterial genera were positively associated

with each other.

\section{DISCUSSION}

centuries (He, et al., 2011; Li, et al., 2016). It is considered an analog of cheese and prepared from milk of Yak.

As Qula was generally made by natural fermentation without inoculating any commercial starter cultures, it is a typical case study for food biogeography. In this research, bacterial diversity in Qula from Yunnan, Xizang, 
235

starter is used to inoculate unpasteurized yak milk, and naturally occurring microorganisms serve as the inoculums instead. Therefore, the process of fermentation is largely affected by the local 'house flora' (Santos, et al., 1998). The five sampling locations have different local 'house flora', which may lead to significant differences in the microbial community between samples. Similar reports were found for the fermented yak milk in Tibet, Plaisentif cheese in Italy (Wu, et al., 2009; Dalmasso, et al., 2016). Milk composition may also influence fermentation microbiota in dairy fermentations (Sun, et al., 2014; Bokulich, et al., 2015; Dalmasso, et al., 2016). The composition of yak milk is affected by many factors including breed, diet, and parity. Milks from different yak breeds can contain widely different contents of fat, protein, lactose and other nutrients (He, et al., 2011). Diet is another important factor influencing the profile of yak milk, which is greatly affected by season (Liu et al., 2011). Liu et al. (2011) also reported differences in composition of yak milk between primiparous and multiparous animals. More work is needed to assess the effect of milk composition on microbiota in raw yak milk and Qula. In the present study, Qula from Yunnan stored for a shorter time (two weeks) had the lowest bacterial richness, while other samples stored for a longer time (more than one month) had higher bacterial richness. Since Qula is usually packaged in bags and kept for a period of time at room temperature before sale, environmental factor will continue shaping the microbiome of Qula during storage. Further studies are needed to assess what role storage condition and time may play on the profile of Qula microbiota.

A variety of microorganisms including various lactic acid bacteria, coliform bacteria, and aerobic bacteria have been found in Qula collected from Qinghai and Gansu (Zhang, et al., 2015). In the present study, a total of 6 bacterial phyla and 73 bacterial genera were identified in the Qula samples from five different regions. Among them, Firmicutes, Proteobacteria, Actinobacteria, and Bacteroidetes were also observed in raw milk 
256 (Zhang, et al., 2017) and fermented milk products such as Plaisentif cheese (Dalmasso, et al., 2016) and tarag

257 (Sun, et al., 2014), but Acidobacteria and Cyanobacteria were not detected in previous studies (Sun, et al.,

2014; Dalmasso, et al., 2016; Zhang, et al., 2017). Most of the bacterial genera detected in the present study

were also observed in tarag, such as Lactobacillus, Streptococcus, Lactococcus, Leuconostoc, Acinetobacter,

Acetobacter, Enterobacter, Enhydrobacter, Bacillus, Macrococcus, Chryseobacterium, Klebsiella, Citrobacter,

and Bifidobacterium (Sun, et al., 2014). Among them, Lactobacillus, Acetobacter, Lactococcus, Leuconostoc,

and Streptococcus were dominant in tarag (Sun, et al., 2014). Some of the bacterial genera were also observed

in raw milk, including Pseudomonas, Staphylococcus, Stenotrophomonas, Janthinobacterium, and

Sphingomonas (Zhang, et al., 2017). Numerous bacterial genera such as Lactobacillus, Lactococcus,

Leuconostoc, Pseudomonas, Staphylococcus, Stenotrophomonas, Chryseobacterium, Enhydrobacter,

Enterococcus, and Sphingomonas have been observed in Plaisentif cheese (Dalmasso, et al., 2016). In previous

studies, some species of bacterial genera such as Lactococcus, Lactobacillus, Enterococcus, Bifidobacterium,

and Weissell have probiotic potential (Sun, et al., 2014; Zhang, et al., 2017). However, members of

Staphylococcus, Enterobacter, Serratia, and Burkholderia have been involved in human infections as

opportunistic pathogens (Iversen, et al., 2003; Munsch-Alatossava, et al., 2006; Raquel, et al., 2016; Visscher,

et al., 2017; Zhang, et al., 2017). Members of the genus Staphylococcus frequently occur in milking animals;

for example, Staphylococcus aureus, which is the most prevalent pathogen in dairy ruminants and often

detected in milk and milk products (Visscher, et al., 2017; Zhang, et al., 2017). Several strains of the genera

Enterobacter, Serratia, and Burkholderia are pathogenic and are considered to be associated with raw milk

275 (Iversen, et al., 2003; Munsch-Alatossava, et al., 2006; Raquel, et al., 2016). The results whether or not the

traditionally prepared homemade Qula is safe needs further verification. 
PICRUSt is a computational approach that can predict the functional composition of a metagenome from 16S data and a reference genome database (Langille, et al., 2013). Such integrated analysis is proved to be cost-effective and helpful for combinational evaluation of the functional and taxonomic properties of the microbiota from human, soils, mammalian guts and others (Ryo, et al., 2017; Pavloudi, et al., 2017; Zeng, et al., 2017; Wu, et al., 2018). In the present study, Amino acid metabolism and carbohydrate metabolism were the main metabolic pathways identified for bacteria in all Qula samples, similar results were found for the raw milk from goats (Zhang, et al., 2017). The dominant metabolic pathways may relate to some certain bacteria in certain circumstances (Zhang, et al., 2017). PICRUSt predictions could also likely be improved by including habitat information in a predictive model, because some genes might correlate strongly with environmental parameters as well as phylogenetic similarity to reference organisms (Langille, et al., 2013). In the present study, the reason why bacterial communities would shift with respect to functional genes can't be explained due to lack of specific environmental information. Hence, further studies on isolation and cultivation of bacteria from these samples are needed, in order to illuminate metabolic pathways of certain bacteria in certain circumstances.

Microorganisms do not exist in isolation, but instead form complex and interacting ecological webs (William and Lidicker, 1979; Konopka, 2009; Freilich, et al., 2010). Microbial networks have been inferred for a range of communities, from soil and ocean communities to human body communities (Faust and Raes, 2012; Zhou, et al., 2010; Arumugam, et al., 2011). In the bacterial network, most of bacterial genera were positively associated with each other. All the negative interactions were related to Lactobacillus, Acetobacter, and Gluconobacter. Lactobacillus can produce either alcohol or lactic acid from sugars, which is mainly applied to ferment traditional food and beverages (Makarova, et al., 2006). Acetobacter is characterized by the ability to 
298

convert ethanol to acetic acid in the presence of oxygen, and is used for producing vinegar (Cleenwerck, et al., 2002). Gluconobacter, which can also oxidize ethanol into acetic acid, was related to beer spoilage and rot in fruits (Spitaels, et al., 2014). The metabolic products (e.g., alcohol, lactic acid, acetic acid) of them have antibacterial activity and can inhibit the growth of other pathogenic and food spoilage bacteria, which was in agreement with some previous studies (Sun, et al., 2014; Zhang, et al., 2015). Since compositional data have a negative correlation bias (Pearson, 1987), more rigorous approaches including SPARCC (Friedman and Alm, 2012) and SPieCeasi (Kurtz et al.,2015) should be applied to analyze correlation to illuminate the relationship of the microbes in the process of Qula production and storage.

\section{CONCLUSIONS}

Pyrosequencing has been shown to be a powerful tool in exploring a large diversity of natural environments.

However, until recently few studies have considered food microbiota. In this study, microbial diversity and communities in Qula samples from different regions in China were studied using high-throughput sequencing.

This is the first study to apply this technology to study food ecology in Qula. The results provided insights into the impact of environment on bacterial communities in Qula and lay a foundation for further investigations into the food ecology of Qula.

\section{REFERENCES}

Ao X, Zhang X, Zhang X, Shi L, Zhao K,Yu J, Dong L, Cao Y, Cai Y. 2012.Identification of lactic acid bacteria in traditional fermented yak milk and evaluation of their application in fermented milk products.Journal of Dairy Science 95:1073-1084 DOI: 10.3168/jds.2011-4224.

Arumugam M, Jeroen R, Eric P, Denis Le P, Takuji Y, Daniel R, Gabriel R, Julien T, Thomas B, Jean-Michel B, Marcelo B, Natalia B, Francesc C, Leyden F, Laurent G, Torben H, Masahira H, Tetsuya H, Michiel K, Ken K, Marion L, Florence L, Chaysavanh M, Bjrn Nielsen H, Trine N, Nicolas P, Julie P, Junjie Q, 
Thomas S. 2011. Enterotypes of the human gut microbiome. Nature 473:174-180 DOI 10.1038/nature09944.

Barberán A, Bates ST, Casamayor EO, Fierer N. 2012. Using network analysis to explore co-occurrence patterns in soil microbial communities. The ISME journal6:343-351 DOI 10.1038/ismej.2011.119.

Bokulich NA, Amiranashvili L, Chitchyan K, Ghazanchyan N, Darbinyan K, Gagelidze N, Sadunishvili T, Goginyan V, Kvesitadze G, Torok G, Mills DA. 2015. Microbial biogeography of the transnational fermented milk matsoni. Food Microbiology 50:12-19 DOI 10.1016/j.fm.2015.01.018.

Caporaso JG, Kuczynski J, Stombaugh J, Bittinger K, Bushman FD, Costello EK, Fierer N, Peña AG, Goodrich JK, Gordon JI, Huttley GA, Kelley ST, Knights D, Koenig JE, Ley RE, Lozupone CA, McDonald D, Muegge BD, Pirrung M, Reeder J, Sevinsky JR, Turnbaugh PJ, Walters WA, Widmann J, Yatsunenko T, Zaneveld J, Knight R. 2010.QIIME allows analysis of high-throughput community sequencing data. Nature Methods 7:335-336 DOI 10.1038/nmeth.f.303.

Caporaso JG, Lauber CL, Walters WA, Berg-Lyons D, Huntley J, Fierer N, Owens SM, Betley J, Fraser L, Bauer M, Gormley N, Gilbert JA, Smith G, Knight R. 2012.Ultra-high throughput microbial community analysis on the Illumina Hi Seq and Mi Seq platforms. The ISME journal 6:1621-1624 DOI 10.1038/ismej.2012.8.

Chen C, Xiang JY, Hu W, Xie YB, Wang TJ, Cui JW. 2015. Identification of key micro-organisms involved in Douchi fermentation by statistical analysis and their use in an experimental fermentation. Journal of Applied Microbiology 119:1324-1334 DOI 10.1111/jam.12917.

Cleenwerck I, Vandemeulebroecke D, Janssens D; Swings J. 2002.Re-examination of the genus Acetobacter, with descriptions of Acetobacter cerevisiae sp. nov. and Acetobacter malorum sp. nov.. International Journal of Systematic and Evolutionary Microbiology 52:1551-1558 DOI 10.1099/00207713-52-5-1551.

Cui GX,Yuan F, Degen AA, Liu SM, Zhou JW, Shang ZH, Ding LM, Mi JD, Wei XH, Long RJ. 2016. Composition of the milk of yaks raised at different altitudes on the Qinghai-Tibetan Plateau. International Dairy Journal 59:29-35 DOI 10.1016/j.idairyj.2016.02.046.

Dalmasso A, Soto del Rio M de los D, Civera T,Pattono D, Cardazzo B, Bottero MT. 2016.Characterization of microbiota in Plaisentif cheese by high-throughput sequencing. LWT-Food Science and Technology 
347

348

349

350

351

352

353

354

355

356

357

358

359

360

361

362

363

364

365

366

367

368

369

370

371

372

373

69:490-496 DOI 10.1016/j.lwt.2016.02.004.

Ding WR, Wang LN, Zhang J, Ke WC, Zhou JW, Zhu JX, Guo XS, Long RJ. 2017. Characterization of antioxidant properties of lactic acid bacteria isolated from spontaneously fermented yak milk in the Tibetan Plateau. Journal of Functional Foods 35:481-488 DOI 10.1016/j.jff.2017.06.008.

Duan YH, Tan ZF, Wang YP, Li ZW, Qin GY, Huo YP, Cai YM. 2008. Identification and characterization of lactic acid bacteria isolated from Tibetan Qula cheese. The Journal of General and Applied Microbiology 54:51-60 DOI 10.2323/jgam.54.51.

Edgar RC, Haas BJ, Clemente JC, Quince C, Knight R. 2011. UCHIME improves sensitivity and speed of chimera detection.Bioinformatics27:2194-2200 DOI 10.1093/bioinformatics/btr381.

Faust K, Raes J. 2012. Microbial interactions: from networks to models. Nature Reviews Microbiology 10:538550 DOI 10.1038/nrmicro2832.

Feng LJ, Chen K, Han DD, Zhao J, Lu Y, Yang GF, Mu J, Zhao XJ. 2017. Comparison of nitrogen removal and microbial properties in solid-phase denitrification systems for water purification with various pretreated lignocellulosic carriers. Bioresource technology 224:236-245 DOI 10.1016/j.biortech.2016.11.002.

Freilich S, Kreimer A, Meilijson I, Gophna U, Sharan R. 2010.The large scale organization of the bacterial network of ecological co-occurrence interactions. Nucleic Acids Research 38:3857-3868 DOI 10.1093/nar/gkq118.

Friedman J, Alm EJ. 2012. Inferring correlation networks from genomic survey data. PLoS computational biology 8:e1002687 DOI 10.1371/journal.pcbi.1002687.

Fu YJ, Li X, Zheng SH, Du J, Liang AH. 2015. Classification and identification of bacteria in the soil treated by AcMNPV using high-throughput sequencing technique. Biotechnology and Bioprocess Engineering 20:931-936 DOI 10.1007/s12257-015-0228-4.

He SH, Ma Y, Wang JQ, Li QM, Yang X, Tang SH, Li HM. 2011. Milk fat chemical composition of yak breeds in China. Journal of Food Composition and Analysis 24:223-230 DOI 10.1016/j.jfca.2010.07.008

Huang YH, Yi ZL, Jin YL, Zhao YG, He KZ, Liu DY, Zhao D, He H, Luo HB, Zhang WX, Fang Y, Zhao H. 2017. New microbial resource: microbial diversity, function and dynamics in Chinese liquor starter. 
375

Ihaka R, Gentleman R. 1996. R: A Language for Data Analysis and Graphics. Journal of Computational and Graphical Statistics 5:299-314 DOI 10.2307/1390807.

Iversen C, Forsythe S. 2003. Risk profile of Enterobacter sakazakii, an emergent pathogen associated with infant milk formula. Trends in food science and technology 14: 443-454 DOI 10.1016/S09242244(03)00155-9.

Kanehisa M, Goto S, Sato Y, Furumichi M, Tanabe M. 2012. KEGG for integration and interpretation of large-scale molecular data sets. Nucleic Acids Research 40:D109-D114 DOI 10.1093/nar/gkr988.

Konopka A. 2009. What is microbial community ecology? The ISME Journal 3:1223-1230 DOI 10.1038/ismej.2009.88.

Kryachko Y, Dong XL, Sensen CW, Voordouw G. 2012. Compositions of microbial communities associated with oil and water in a mesothermic oil field. Antonie Van Leeuwenhoek 101:493-506 DOI 10.1007/s10482-011-9658-y.

Kurtz Z D, Müller CL, Miraldi ER, Littman DR, Blaser MJ, and Bonneau RA. 2015. Sparse and compositionally robust inference of microbial ecological networks. PLoS computational biology 11:e1004226 DOI 10.1371/journal.pcbi.1004226.

Langille MGI, Zaneveld J, Caporaso JG, McDonald D, Knights D, Reyes JA, Clemente JC, Burkepile DE, Thurber RLV, Knight R. 2013. Predictive functional profiling of microbial communities using16S rRNA marker gene sequences. Nature Biotechnology 31: 814-821 DOI 10.1038/nbt.2676.

Lenchi N, Inceoğ lu O, Kebbouche-Gana S, Gana ML, Llirós M, Servais P, Garcĭa-Armisen T. 2013. Diversity of microbial communities in production and injection waters of algerian oilfields revealed by $16 \mathrm{~S}$ rRNA gene amplicon 454 pyrosequencing. PLOS ONE 8: e66588 DOI 10.1371/journal.pone.0066588.

Li HM, Ma Y, Dong AJ, Wang JQ, Li QM, He SH, Maubois JL. 2010. Protein composition of yak milk. Dairy Science and Technology 90:111-117 DOI 10.1051/dst/2009048.

Li J, Ren FZ, Gu HY, Li XP, Gan BZ. 2011. Safety evaluation in vitro of Enterococcus durans from Tibetan traditional fermented yak milk. The Journal of Microbiology 5:721-728 DOI 10.1007/s12275-011-1062-9.

Liu HN, Ren FZ, Jiang L, Ma ZL, Qiao HJ, Zeng SS, Gan BZ, Guo HY. 2011. Fatty acid profile of yak milk 
401

402

403

404

405

406

407

408

409

410

411

412

413

414

415

416

417

418

419

420

421

422

423

424

425

426

427

from the Qinghai-Tibetan Plateau indifferent seasons and for different parities. Journal of Dairy Science 94:1724-1731 DOI 10.3168/jds.2010-3749.

Liu ZZ, Lozupone C, Hamady M, Bushman FD, Knight R. 2007. Short pyrosequencing reads suffice for accurate microbial community analysis. Nucleic Acids Research 35:e120 DOI: 10.1093/nar/gkm541.

Makarova K, Slesarev A, Wolf Y, Sorokin A, Mirkin B, Koonin E, Pavlov A, Pavlova N. 2006. Comparative genomics of the lactic acid bacteria. Proceedings of the National Academy of Sciences of the United States of America 103:15611-15616 DOI 10.1073/pnas.0607117103.

Munsch-Alatossava P, Alatossava T. 2006. Phenotypic characterization of raw milk-associated psychrotrophic bacteria. Microbiological Research 161:334-346 DOI 10.1016/j.micres.2005.12.004.

Pearson K. 1897. Mathematical contributions to the theory of evolution. - on a form of spurious correlation which may arise when indices are used in the measurement of organs. Proceedings of the Royal Society of London 60, 489-498.

Polka J, Rebecchi A, Pisacane V, Morelli L, Puglisi E. 2015. Bacterial diversity in typicalltalian salami at different ripening stages as revealed by high-throughput sequencing of $16 \mathrm{~S}$ rRNA amplicons. Food Microbiology 46:342-356 DOI 10.1016/j.fm.2014.08.023.

Raquel L, Mark ST, Mike W, Nidhi B. 2016. Culture-independent bacterial community profiling of carbon dioxide treated raw milk. International Journal of Food Microbiology 233: 81-89 DOI 10.1016/j.ijfoodmicro.2016.06.015.

Ryo I, Ryuji OK, Takamitsu T, Masashi T, Shinya M, Takayuki I, Hajime Y, Toru K, Koji H, Akira S, Noriko SA. 2017. Prediction of functional profiles of gut microbiota from 16S rRNA metagenomic data provides a more robust evaluation of gut dysbiosis occurring in Japanese type 2 diabetic patients. Journal of Clinical Biochemistry and Nutrition 61:217-221 DOI 10.3164/jcbn.17-44.

Santos EM, GonzalezFernandez C, Jaime I, Rovira J. 1998. Comparative study of lactic acid bacteria house flora isolated in different varieties of chorizo. International Journal of Food Microbiology 39:123-128 DOI 10.1016/S0168-1605(97)00128-1.

Schlosset PD, Westcott SL, Ryabin T, Hall JR, Hartmann M, Hollister EB, Lesniewski RA, Oakley BB, Parks DH, Robinson CJ, Sahl JW, Stres B, Thallinger GG, Van Horn DJ, Weber CF. 2009. Introducing mothur: 
Opensource, platform-independent, community supported software for describing and comparing microbial communities. Applied and Environmental Microbiology 75:7537-7541 DOI 10.1128/AEM.01541-09.

Shannon P, Markiel A, Ozier O, Baliga NS, Wang JT, Ramage D, Amin N, Schwikowski B, and Ideker T. 2003. Cytoscape: A Software Environment for Integrated Models of Biomolecular Interaction Networks. Genome Research 13:2498-2504 DOI 10.1101/gr.1239303.

Solieri L, Dakal TC, Giudici P. 2013. Next-generation sequencing and its potential impact on food microbial genomics. Annals of Microbiology 63:21-37 DOI 10.1007/s13213-012-0478-8.

Spitaels F, Wieme A, Balzarini T, Cleenwerck I, Van LA, De VL, Vandamme P. 2014. Gluconobacter cerevisiae sp. nov., isolated from the brewery environment. International Journal of Systematic and Evolutionary Microbiology 64:1134-41. DOI 10.1099/ijs.0.059311-0.

Sun Z, Liu W, Gao W, Yang M, Zhang J, Wu L, Wang J, Menghe B, Sun T, Zhang H. 2010. Identification and characterization of the dominant lactic acid bacteria from kurut: The naturally fermented yak milk in Qinghai,China. The Journal of General and Applied Microbiology 56:1-10 DOI 10.2323/jgam.56.1

Sun ZH, Liu WJ, Bao QH, Zhang JC, Hou QC, Kwok LY, Sun TS, Zhang HP. 2014. Investigation of bacterial and fungal diversity in tarag using high-throughput sequencing. Journal of Dairy Science 97:6085-6096 DOI 10.3168/jds.2014-8360.

Tago K, Itoh H, Kikuchi Y, Hori T, Sato Y, Nagayama A, Okubo T, Navarro R, Aoyagi T, Hayashi K, Hayatsu M. 2014. A fine-scale phylogenetic analysis of free-living Burkholderia species in sugarcane field soil. Microbes and Environments 29:434-437 DOI 10.1264/jsme2.ME14122.

Visscher AD, Piepers S, Haesebrouck F, Supré K, Vliegher SD. 2017. Coagulase-negative Staphylococcus species in bulk milk: Prevalence, distribution, and associated subgroup and species-specific risk factors. Journal of Dairy Science 100:629-642 DOI 10.3168/jds.2016-11476.

Wang Q, Garrity GM, Tiedje JM, and Cole JR. 2007. Naive Bayesian classifier for rapid assignment of rRNA sequences into the new bacterial taxonomy. Applied and Environmental Microbiology 73:5261-5267 DOI 10.1128/AEM.00062-07.

William Z, Lidicker J. 1979. A clarification of interactions in ecological systems. Bioscience 29: 475-477 DOI 
455

456

457

458

459

460

461

462

463

464

465

466

467

468

469

470

471

472

473

474

475

476

477

478

479

480

481

10.2307/1307540.

Wu J, Peters BA, Dominianni C, Zhang YL, Pei ZH, Yang LY, Ma YF, Purdue MP, Jacobs EJ, Gapstur SM, Li HL, Alekseyenko AV, Hayes RB, Ahn J. 2016. Cigarette smoking and the oral microbiome in a large study of American adults. The ISME Journal10: 2435-2446 DOI 10.1038/ismej.2016.37.

Wu XH, Luo Z, Yu L, Ren FZ, Han BZ, Robert Nout MJ. 2009. A survey on composition and microbiota of fresh and fermented yak milk at different Tibetan altitudes. Dairy Science and Technology 89:201-209 DOI $10.1051 / \mathrm{dst} / 2009007$.

Wu Y, Chi X, Zhang Q, Chen F, Deng X. 2018. Characterization of the salivary microbiome in people with obesity. PeerJ 6:e4458 DOI 10.7717/peerj.4458.

Xu D, Liu S, Chen Q, Ni J. 2017. Microbial community compositions in different functional zones of Carrousel oxidation ditch system for domestic wastewater treatment. AMB Express7: 40 DOI 10.1186/s13568-017-0336-y.

Yang L, Yang HL, Tu ZC, Wang XL. 2016. High-throughput sequencing of microbial community diversity and dynamics during douchi fermentation. PLOS ONE 11:1-19 DOI 10.1371/journal.pone.0168166.

Zeng S, Huang Z, Hou D, Liu J, Weng S, He J. 2017. Composition, diversity and function of intestinal microbiota in pacific white shrimp (Litopenaeus vannamei) at different culture stages. Peer J 5:e3986 DOI 10.7717/peerj.3986.

Zhang B, Tan ZF, Wang YP, Li ZW, Jiao Z, Huang Q. 2015. Dynamic changes of the microbial communities during the preparation of traditional Tibetan Qula cheese. Dairy Science and Technology 95:167-180 DOI 10.1007/s13594-014-0194-1.

Zhang F, Wang Z, Lei F, Wang B, Jiang S, Peng Q, Zhang J, Shao Y. 2017. Bacterial diversity in goat milk from the Guanzhong area of China.Journal of Dairy Science 100:7812-7824 DOI 10.3168/jds.201713244.

Zhang W, Luo Q, Zhu Y, Ma J, Cao L, Yang M, Wen PC, Zhang ZM, He XL .2018.Microbial diversity in two traditional bacterial douchi from Gansu province in northwest China using Illumina sequencing. PLOS ONE 13(5): 0194876 DOI 10.1371/journal.pone.0194876.

Zhang Y, Skaar I, Sulyok M, Liu X, Rao M, Taylor JW. 2016. The microbiome and metabolites in fermented 
482

Pu-erh Tea as revealed by high-throughput sequencing and quantitative multiplex metabolite analysis. PLoS ONE 11:1-18 DOI 10.1371/journal.pone.0157847.

Zhou J, Deng Y, Luo F, He Z, Tu Q, Zhi X. 2010. Functional molecular ecological networks. mBio1:e00169e00110 DOI 10.1128/mBio.00169-10.

\section{Figure legends}

Figure 1: Rarefaction curves for Shannon diversity indices of bacteria in the samples.

Figure 2: Linear discriminant analysis of microbial community compositions in Qula samples. The node size represents the difference in relative abundance. Yellow nodes indicate OTUs with no significant differences in relative abundance. Red, green, blue, purple, and blue-green nodes indicate OTUs with significant differences in Qula samples from Gansu, Qinghai, Sichuan, Xizang, Yunnan. The meaning of shading color is the same as node color.

Figure 3: Principal coordinate analysis $(\mathrm{PCoA})$ of bacteria genera based on the unweighted UniFrac distance among samples.

Figure 4: Unweighted pair-group analysis (UPGMA) of bacteria using arithmetic means based on unweighted UniFrac analysis.

Figure 5: Heatmap and dendrogram of top 50 bacterial genera present in the samples. Color blocks represent the relative abundance of genera, namely the $\mathrm{Z}$ value. More red indicates a higher relative abundance.

Figure 6: Heatmap of clustering analysis based on the functional genes in the samples.

Figure 7: Networks of microbial interaction in the samples. Each node represents a bacterial genus, edges denote significant correlations between phylotypes (Spearman's $\rho>0.6$ ). Positive correlations colored in green indicate co-occurrence, whereas negative correlations in red indicate mutual exclusion. 
Figure 1

Rarefaction curves for Shannon diversity indices of bacteria in the samples

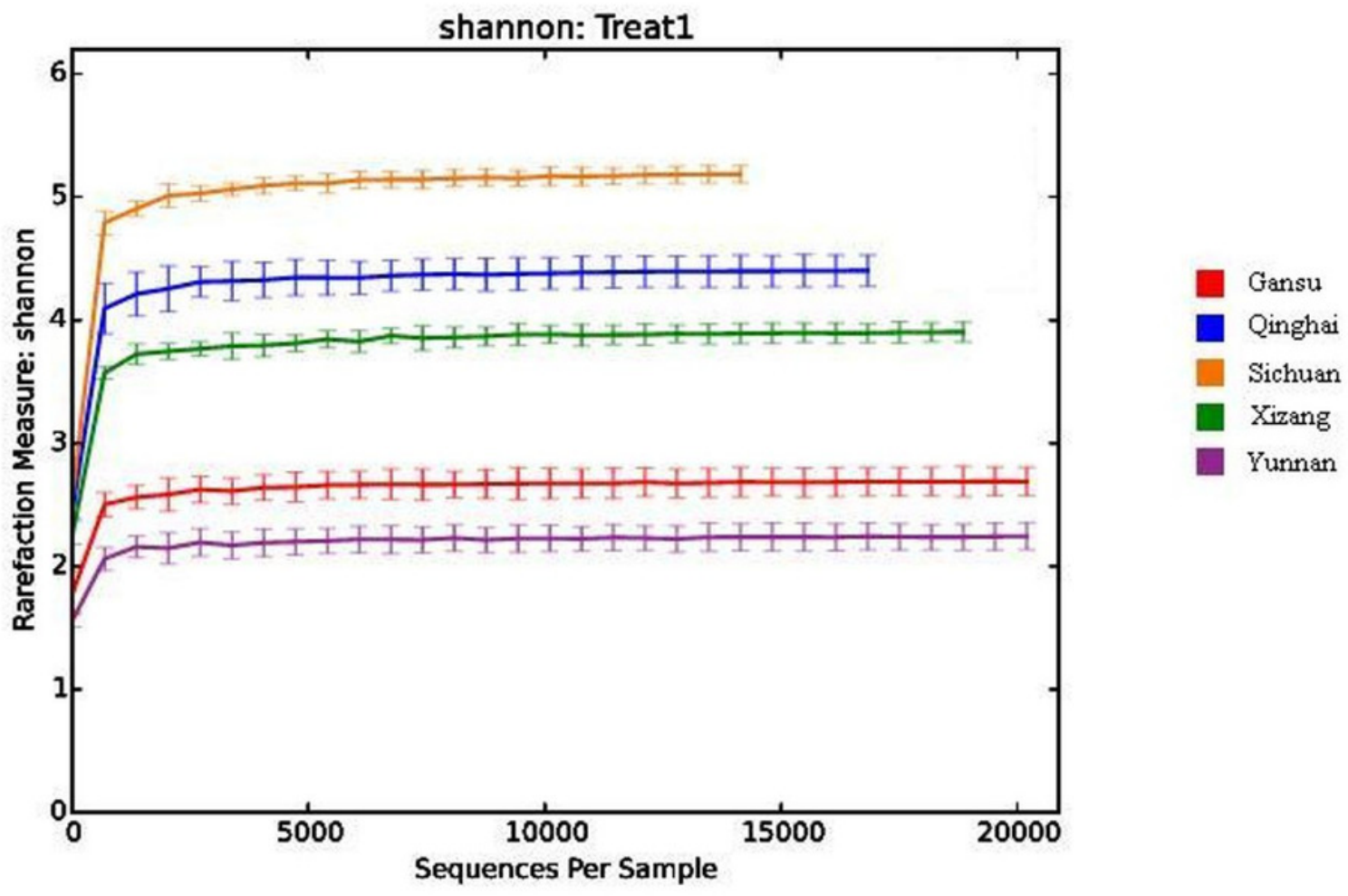


Figure 2

Linear discriminant analysis of microbial community compositions in Qula samples.

The node size represents the difference in relative abundance. Yellow nodes indicate OTUs

with no significant differences in relative abundance. Red, green, blue, purple, and blue-

green nodes indicate OTUs with significant differences in Qula samples from Gansu, Qinghai,

Sichuan, Xizang, Yunnan. The meaning of shading color is the same as node color

\section{Cladogram}
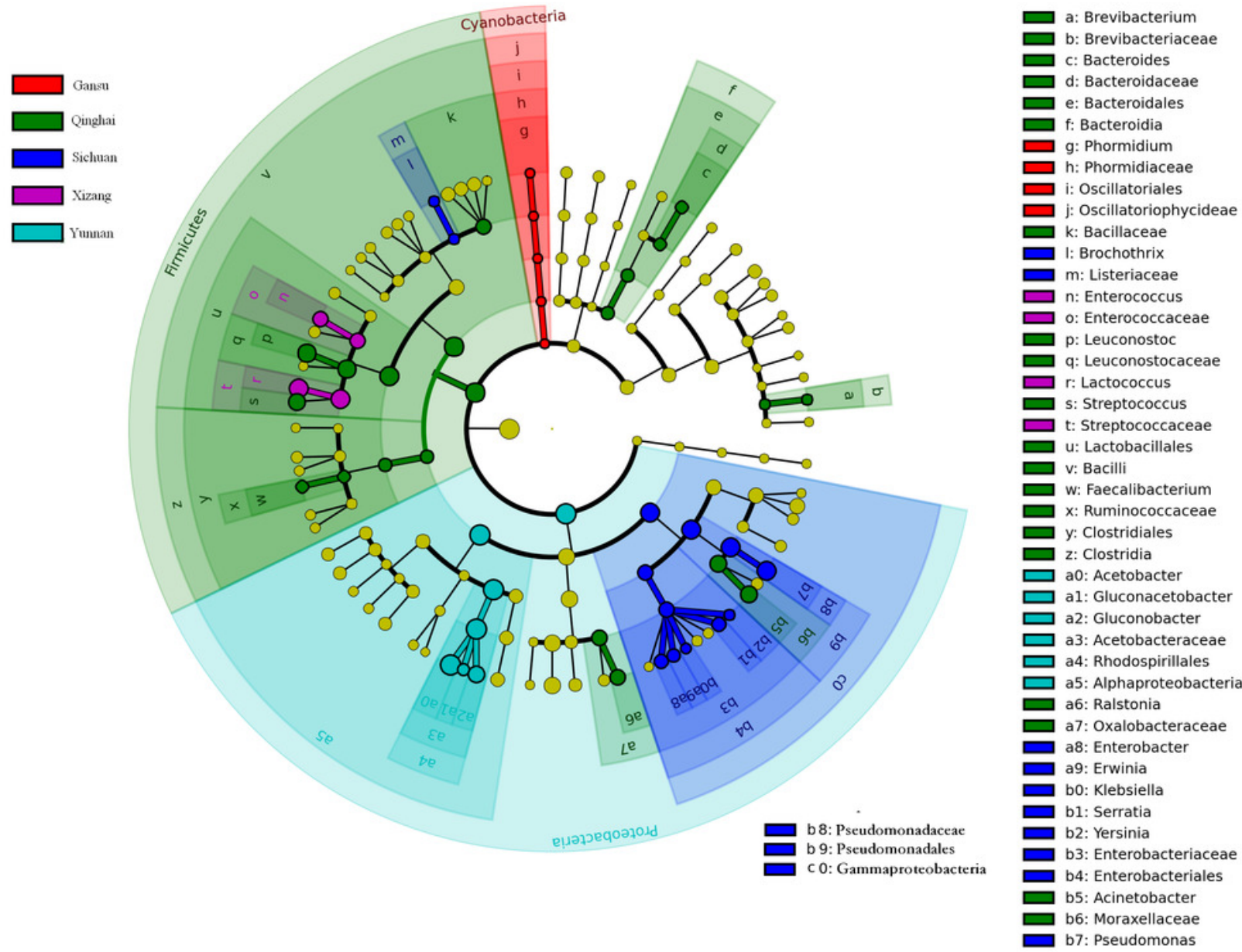
Figure 3

Principal coordinate analysis (PCOA) of bacteria genera based on the unweighted UniFrac distance among samples

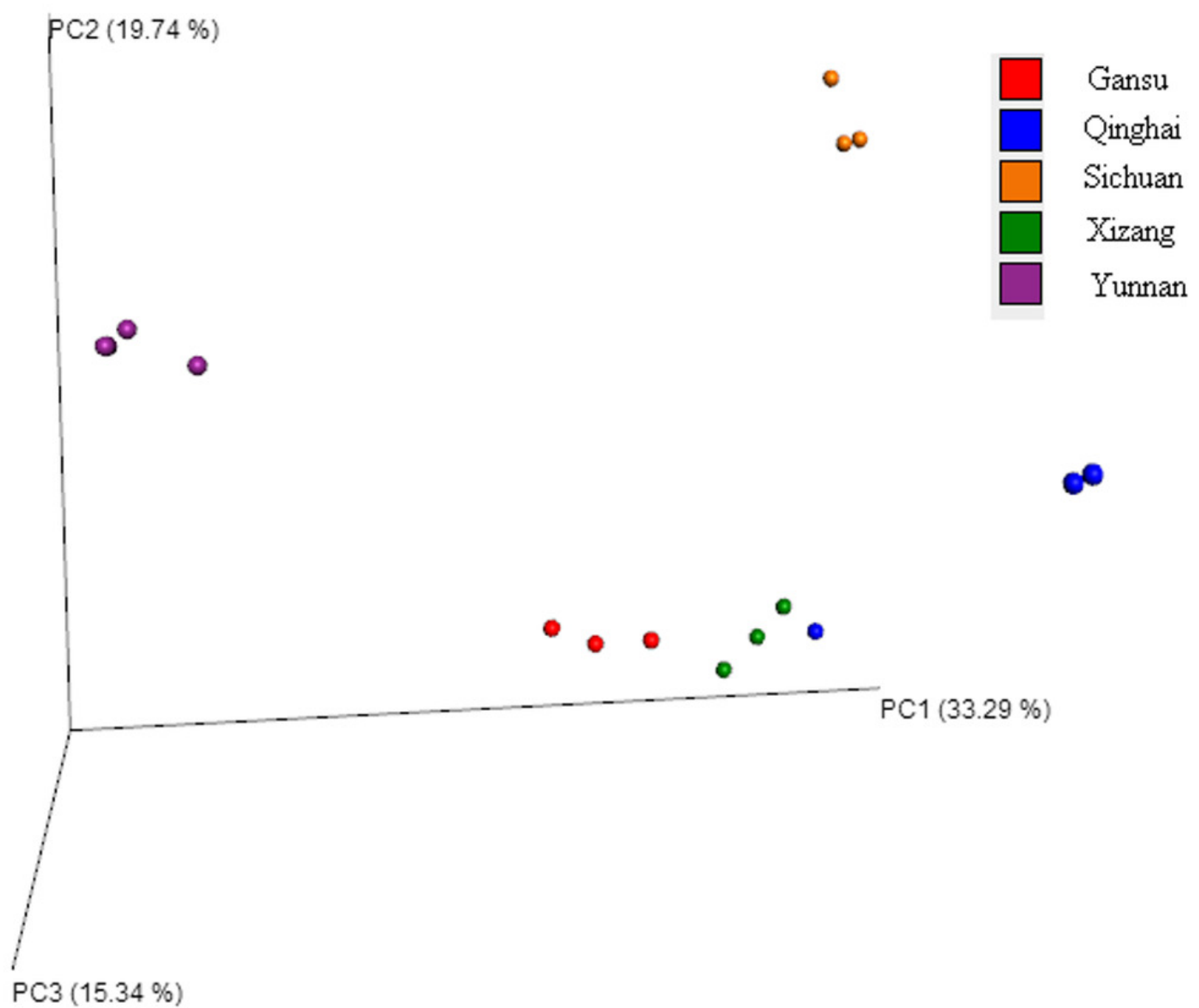


Figure 4

Unweighted pair-group analysis (UPGMA) of bacteria using arithmetic means based on unweighted UniFrac analysis.

*Note: Auto Gamma Correction was used for the image. This only affects the reviewing manuscript. See original source image if needed for review.

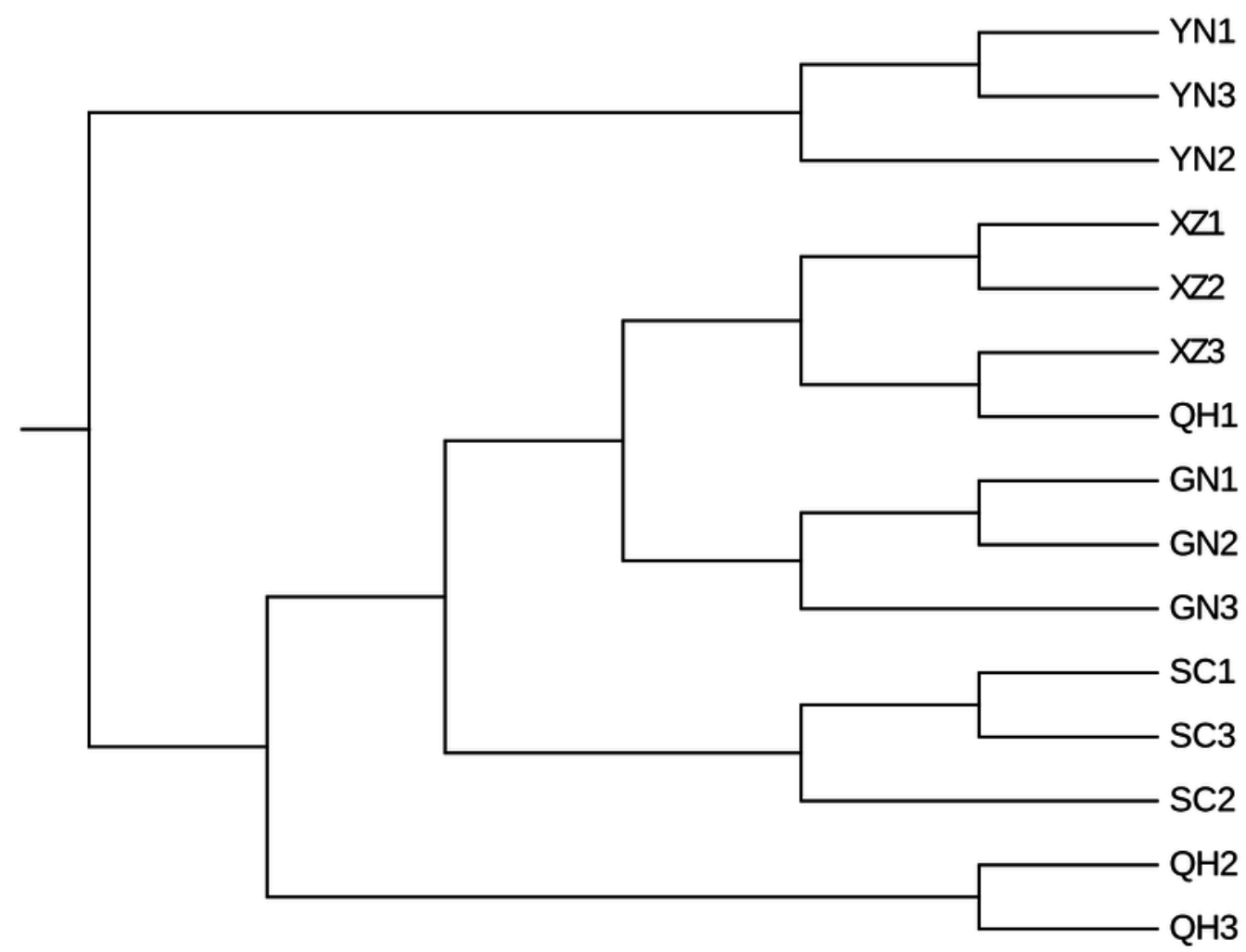




\section{Figure 5}

Heatmap and dendrogram of top 50 bacterial genera present in the samples.

Color blocks represent the relative abundance of genera, namely the $Z$ value. More red indicates a higher relative abundance.

*Note: Auto Gamma Correction was used for the image. This only affects the reviewing manuscript. See original source image if needed for review.

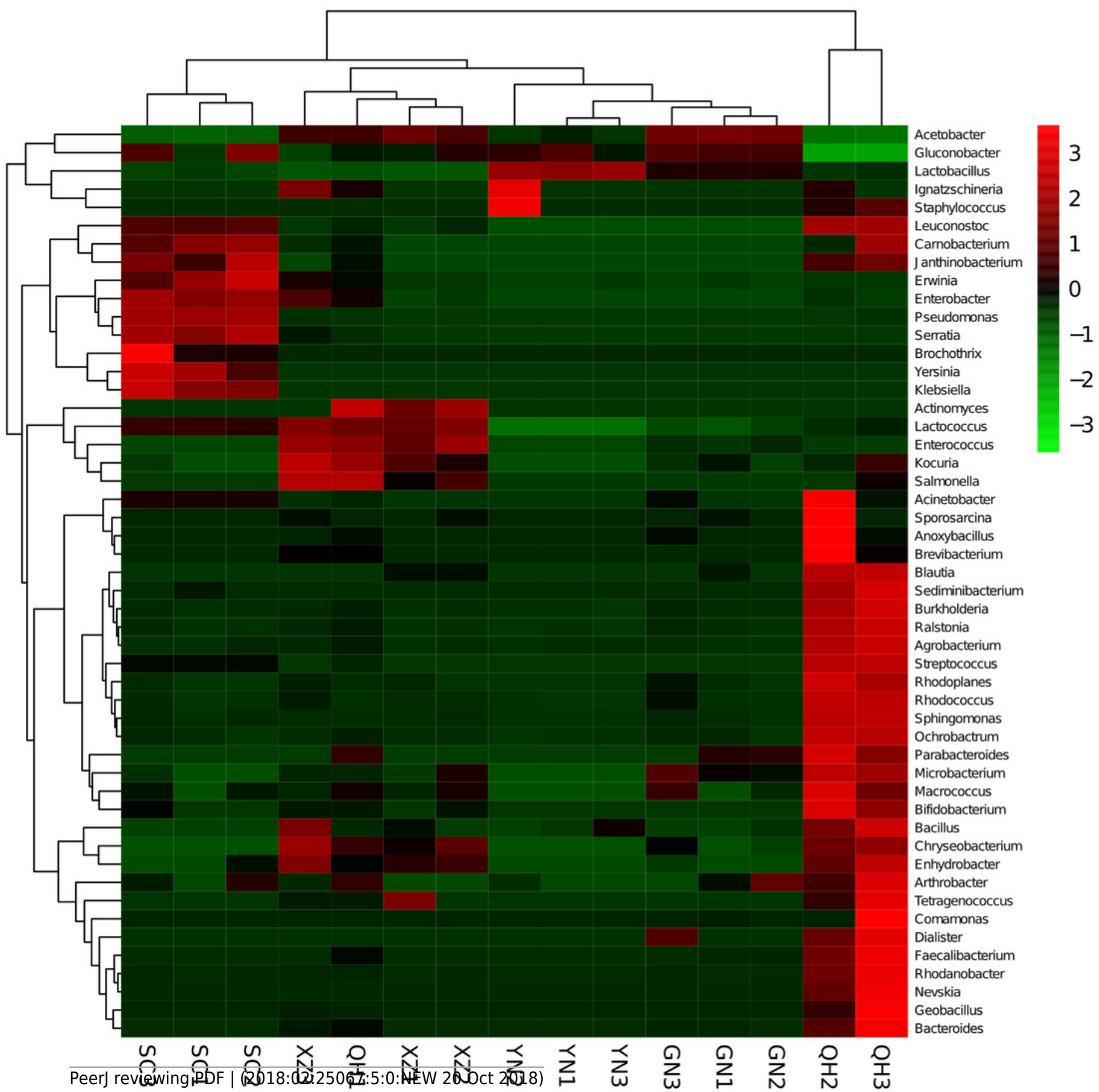




\section{Figure 6}

\section{Heatmap of clustering analysis based on the functional genes in the samples .}

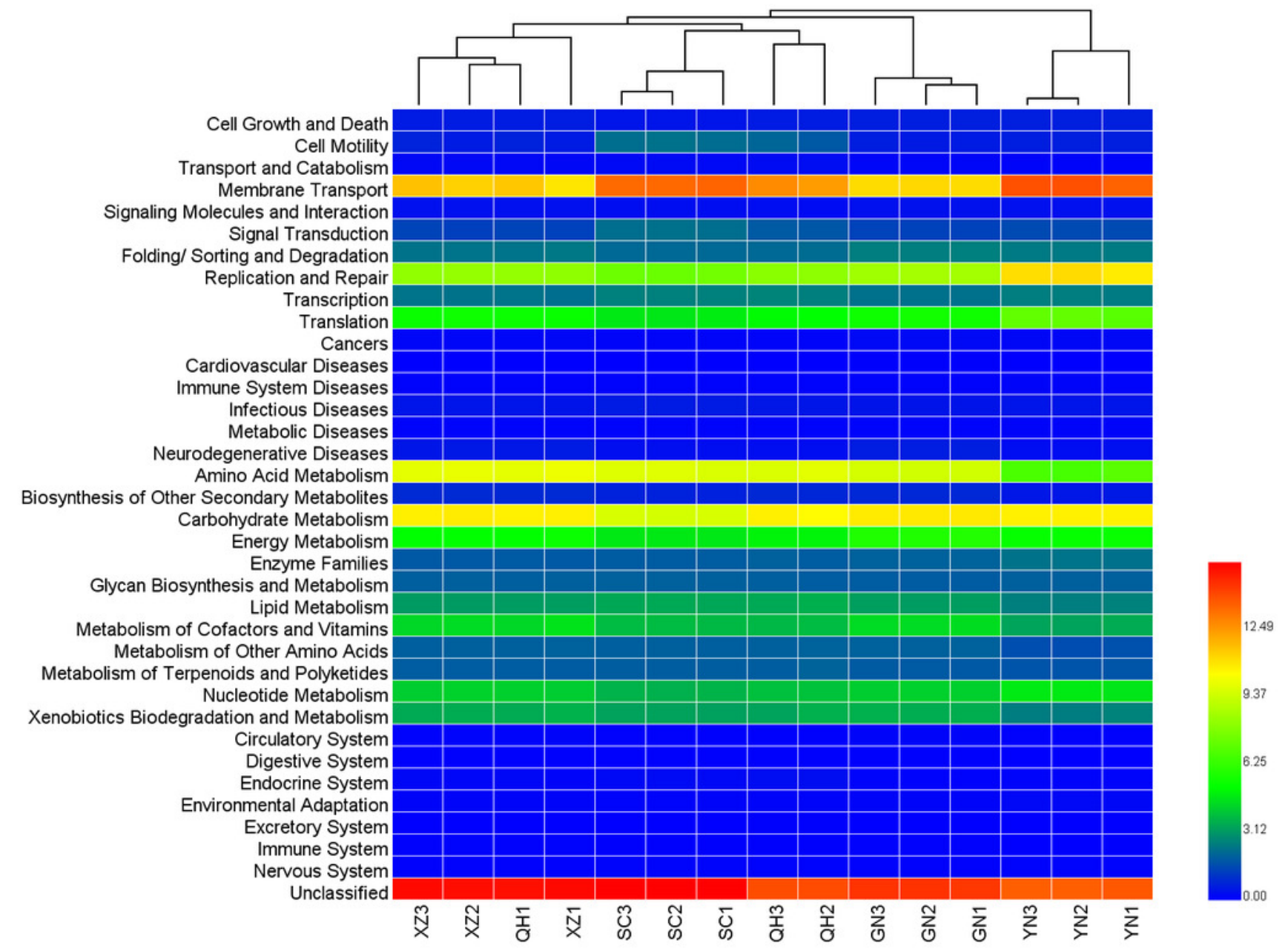




\section{Figure 7}

Networks of microbial interaction in the samples.

Each node represents a bacterial genus, edges denote significant correlations between phylotypes (Spearman's $\rho>0.6$ ). Positive correlations colored in green indicate cooccurrence, whereas negative correlations in red indicate mutual exclusion.

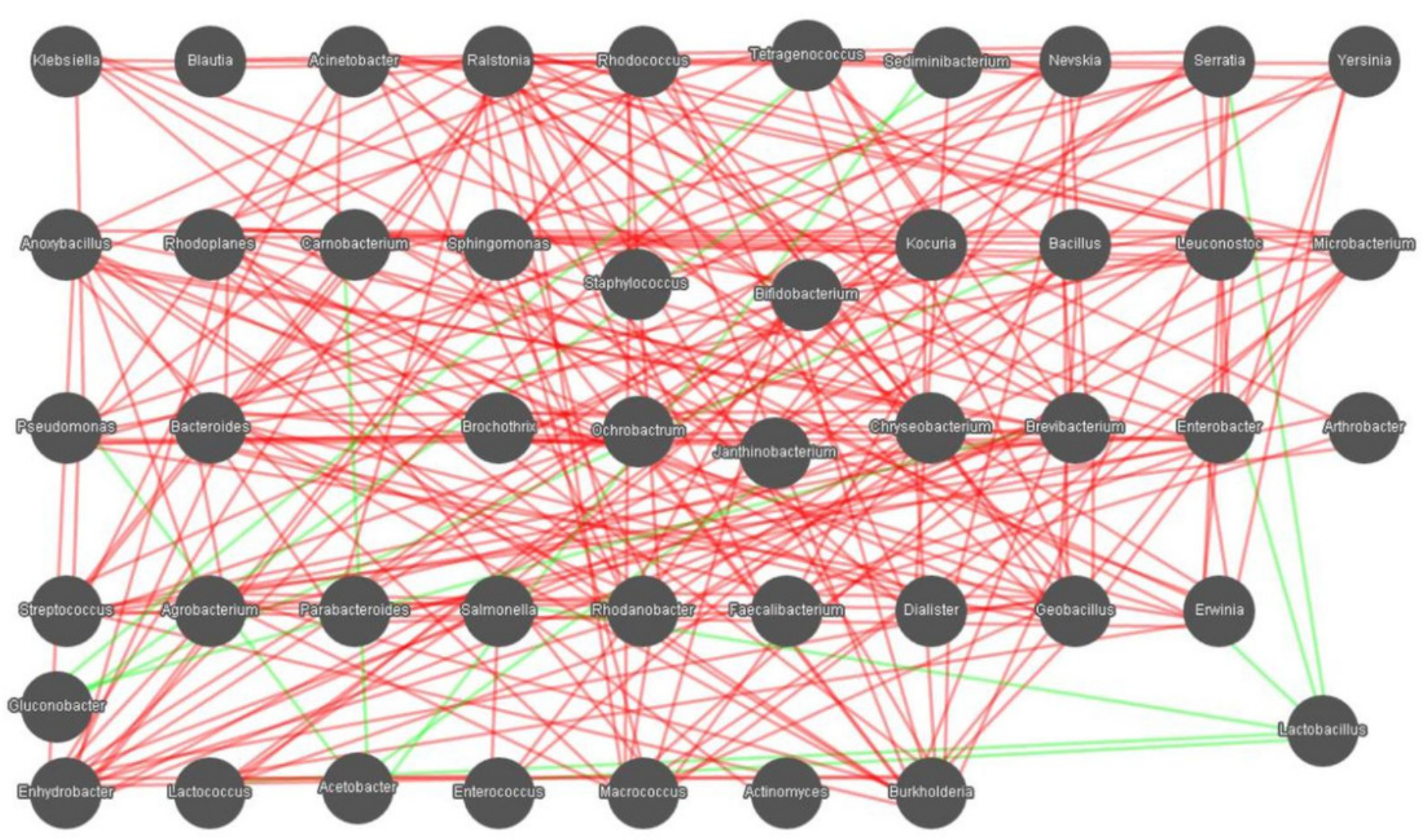


Table $\mathbf{1}$ (on next page)

Information of Qula samples from diffrent origins 
Table 1 Information of Qula samples from diffrent origins

\begin{tabular}{clll}
\hline Sample ID & Color & Sample location & Origin \\
\hline YN1 & White & Yunnan province,China & Xiangelila (27.31 N 95.52 E) \\
YN2 & White & Yunnan province,China & Xiangelila (27.31 N 95.52 E) \\
YN3 & White & Yunnan province,China & Xiangelila (27.31 N 95.52 E) \\
XZ1 & Yellow & Xizang province,China & Shannan (29.23 N 91.77 E) \\
XZ2 & Yellow & Xizang province,China & Shannan (29.23 N 91.77 E) \\
XZ3 & Yellow & Xizang province,China & Shannan (29.23 N 91.77 E) \\
QH1 & Yellow & Qinghai province,China & Huangzhong (36.51 N 101.57 E) \\
QH2 & Yellow & Qinghai province,China & Huangzhong (36.51 N 101.57 E) \\
QH3 & Yellow & Qinghai province,China & Huangzhong (36.51 N 101.57 E) \\
GN1 & Yellow & Gansu province,China & Gannan (34.98 N 102.92 E) \\
GN2 & Yellow & Gansu province,China & Gannan (34.98 N 102.92 E) \\
GN3 & Yellow & Gansu province,China & Gannan (34.98 N 102.92 E) \\
SC1 & Yellow & Sichuan province,China & Kangdin (30.05 N 101.97 E) \\
SC2 & Yellow & Sichuan province,China & Kangdin (30.05 N 101.97 E) \\
SC3 & Yellow & Sichuan province,China & Kangdin (30.05 N 101.97 E) \\
\hline
\end{tabular}

2 
Table 2 (on next page)

OTUs, Good's Coverage, Chaol, and Shannon's indices for 16S r RNA sequencing of the samples 
Table 2 OTUs, Good's Coverage, Chao1, and Shannon's indices for 16S r RNA sequencing of the samples

\begin{tabular}{cccccc}
\hline Sample ID & Reads & OTU & Good's & Chaol & Shannon \\
\hline YN1 & 26688 & 47 & $97.88 \%$ & 194 & 2.32 \\
YN2 & 25003 & 55 & $97.93 \%$ & 181 & 2.07 \\
YN3 & 25344 & 33 & $96.92 \%$ & 184 & 2.16 \\
XZ1 & 23110 & 116 & $97.36 \%$ & 395 & 3.68 \\
XZ2 & 23907 & 114 & $98.56 \%$ & 409 & 3.73 \\
XZ3 & 24756 & 133 & $98.26 \%$ & 437 & 3.86 \\
QH1 & 24869 & 142 & $97.45 \%$ & 305 & 4.12 \\
QH2 & 21213 & 179 & $96.59 \%$ & 268 & 4.23 \\
QH3 & 23102 & 175 & $97.84 \%$ & 297 & 4.48 \\
GN1 & 26439 & 101 & $97.34 \%$ & 223 & 2.43 \\
GN2 & 24801 & 98 & $98.48 \%$ & 260 & 2.73 \\
GN3 & 24688 & 110 & $97.76 \%$ & 252 & 2.61 \\
SC1 & 22156 & 79 & $96.45 \%$ & 421 & 5.04 \\
SC2 & 21424 & 93 & $97.38 \%$ & 439 & 5.08 \\
\hline SC3 & 20087 & 101 & $97.58 \%$ & & 21 \\
\hline
\end{tabular}

2 


\section{Table 3(on next page)}

Percentage of the main bacterial phylum and genus in Qula samples from different regions in China 
Table 3 Percentage of the main bacterial phylum and genus in Qula samples from different regions in China

\begin{tabular}{|c|c|c|c|c|c|}
\hline \multirow{3}{*}{ Bacteria } & \multicolumn{5}{|c|}{ Percentage composition in samples } \\
\hline & Yunnan & Xizang & Qinghai & Gansu & Sichuan \\
\hline & $\mathrm{n}=3$ & $\mathrm{n}=3$ & $\mathrm{n}=3$ & $\mathrm{n}=3$ & $\mathrm{n}=3$ \\
\hline \multicolumn{6}{|l|}{ Phylum } \\
\hline Firmicutes & 79.20 & 51.87 & 64.70 & 45.65 & 57.64 \\
\hline Proteobacteria & 20.80 & 45.91 & 32.7 & 54.18 & 42.24 \\
\hline Actinobacteria & 0.00 & 2.13 & 1.62 & 0.09 & 0.08 \\
\hline Acidobacteria & 0.00 & 0.03 & 0.66 & 0.03 & 0.05 \\
\hline Bacteroidetes & 0.00 & 0.05 & 0.23 & 0.01 & 0.00 \\
\hline Cyanobacteria & 0.00 & 0.01 & 0.04 & 0.03 & 0.00 \\
\hline Unidentified & 0.00 & 0.01 & 0.00 & 0.00 & 0.00 \\
\hline \multicolumn{6}{|l|}{ Genus } \\
\hline Lactobacillus & 79.12 & 5.41 & 14.48 & 36.81 & 13.15 \\
\hline Acetobacter & 17.92 & 41.43 & 14.06 & 50.66 & 5.84 \\
\hline Lactococcus & 0.00 & 41.09 & 23.37 & 7.71 & 26.63 \\
\hline Leuconostoc & 0.00 & 3.52 & 18.97 & 0.10 & 15.26 \\
\hline Streptococcus & 0.00 & 0.01 & 5.43 & 0.01 & 1.25 \\
\hline Acinetobacter & 0.00 & 0.08 & 4.58 & 0.45 & 2.09 \\
\hline Burkholderia & 0.01 & 0.12 & 3.83 & 0.16 & 0.10 \\
\hline Ralstonia & 0.00 & 0.04 & 1.32 & 0.05 & 0.03 \\
\hline Rhodanobacter & 0.00 & 0.03 & 1.20 & 0.02 & 0.03 \\
\hline Pseudomonas & 0.01 & 0.32 & 0.61 & 0.00 & 23.83 \\
\hline Enterococcus & 0.00 & 1.13 & 0.46 & 0.15 & 0.01 \\
\hline Geobacillus & 0.00 & 0.01 & 0.39 & 0.00 & 0.00 \\
\hline Sphingomonas & 0.00 & 0.01 & 0.37 & 0.01 & 0.01 \\
\hline Anoxybacillus & 0.00 & 0.00 & 0.33 & 0.02 & 0.00 \\
\hline Bacillus & 0.05 & 0.14 & 0.30 & 0.02 & 0.00 \\
\hline Rhodococcus & 0.00 & 0.02 & 0.27 & 0.02 & 0.01 \\
\hline Gluconobacter & 0.81 & 0.63 & 0.24 & 0.93 & 0.90 \\
\hline Agrobacterium & 0.00 & 0.01 & 0.23 & 0.00 & 0.00 \\
\hline Ochrobactrum & 0.00 & 0.01 & 0.19 & 0.01 & 0.01 \\
\hline Comamonas & 0.00 & 0.00 & 0.17 & 0.00 & 0.00 \\
\hline Others & 2.07 & 5.99 & 9.20 & 2.86 & 10.85 \\
\hline
\end{tabular}




\section{Table 4 (on next page)}

Functional features relating to metabolism of genes from bacteria in the samples. Letters indicate Duncan's pairwise differences among samples from different origins ( $P$ $<0.05$ ). 
Table 4 Functional features relating to metabolism of genes from bacteria in the samples. Letters indicate Duncan's pairwise differences among samples from different origins $(\mathrm{P}<0.05)$.

\begin{tabular}{|c|c|c|c|c|c|}
\hline \multirow{3}{*}{ Metabolic pathway } & \multicolumn{5}{|c|}{ Percentage composition in samples } \\
\hline & Xizang & Sichuan & Qinghai & Gansu & Yunnan \\
\hline & $\mathrm{n}=3$ & $\mathrm{n}=3$ & $\mathrm{n}=3$ & $\mathrm{n}=3$ & $\mathrm{n}=3$ \\
\hline Amino Acid Metabolism & $10.00 \pm 0.08^{\mathrm{a}}$ & $9.75 \pm 0.08^{\mathrm{bc}}$ & $9.83 \pm 0.12^{\mathrm{ab}}$ & $9.49 \pm 0.04^{\mathrm{d}}$ & $6.81 \pm 0.2^{\mathrm{e}}$ \\
\hline Biosynthesis of Other Secondary Metabolites & $0.87 \pm 0.01^{\mathrm{a}}$ & $0.70 \pm 0.01^{\mathrm{d}}$ & $0.83 \pm 0.03^{\mathrm{b}}$ & $0.82 \pm 0.00^{\mathrm{bc}}$ & $0.50 \pm 0.02^{\mathrm{e}}$ \\
\hline Carbohydrate Metabolism & $10.77 \pm 0.04^{\mathrm{ab}}$ & $9.60 \pm 0.03^{e}$ & $10.66 \pm 0.13^{\mathrm{cd}}$ & $10.87 \pm 0.02^{\mathrm{a}}$ & $10.72 \pm 0.01^{\mathrm{bc}}$ \\
\hline Energy Metabolism & $5.30 \pm 0.11^{\mathrm{bc}}$ & $4.75 \pm 0.01^{\mathrm{e}}$ & $5.08 \pm 0.15^{\mathrm{d}}$ & $5.87 \pm 0.04^{\mathrm{a}}$ & $5.35 \pm 0.04^{\mathrm{b}}$ \\
\hline Enzyme Families & $1.82 \pm 0.01^{\mathrm{e}}$ & $1.89 \pm 0.01^{\mathrm{cd}}$ & $1.91 \pm 0.07^{\mathrm{c}}$ & $2.01 \pm 0.01^{\mathrm{b}}$ & $2.35 \pm 0.03^{\mathrm{a}}$ \\
\hline Glycan Biosynthesis and Metabolism & $1.96 \pm 0.01^{\mathrm{abc}}$ & $1.98 \pm 0.00^{\mathrm{a}}$ & $1.93 \pm 0.03^{\mathrm{d}}$ & $1.89 \pm 0.00^{\mathrm{e}}$ & $1.97 \pm 0.00^{\mathrm{ab}}$ \\
\hline Lipid Metabolism & $3.19 \pm 0.02^{\text {cd }}$ & $3.43 \pm 0.02^{\mathrm{a}}$ & $3.41 \pm 0.02^{\mathrm{ab}}$ & $3.21 \pm 0.03^{\mathrm{c}}$ & $2.61 \pm 0.05^{\mathrm{e}}$ \\
\hline Metabolism of Cofactors and Vitamins & $4.50 \pm 0.12^{\mathrm{a}}$ & $3.82 \pm 0.03^{\mathrm{cd}}$ & $4.00 \pm 0.35^{c}$ & $4.48 \pm 0.02^{\mathrm{ab}}$ & $3.39 \pm 0.09$ \\
\hline Metabolism of Other Amino Acids & $1.97 \pm 0.02^{\mathrm{abc}}$ & $1.95 \pm 0.01^{\mathrm{bcd}}$ & $1.99 \pm 0.03^{\mathrm{ab}}$ & $2.00 \pm 0.01^{\mathrm{a}}$ & $1.60 \pm 0.03^{\mathrm{e}}$ \\
\hline Metabolism of Terpenoids and Polyketides & $1.89 \pm 0.00^{\mathrm{abc}}$ & $1.93 \pm 0.00^{\mathrm{ab}}$ & $1.96 \pm 0.08^{\mathrm{a}}$ & $1.84 \pm 0.01^{\mathrm{cd}}$ & $1.72 \pm 0.01^{\mathrm{e}}$ \\
\hline Nucleotide Metabolism & $4.23 \pm 0.05^{\text {bc }}$ & $3.65 \pm 0.03^{e}$ & $4.05 \pm 0.16^{d}$ & $4.24 \pm 0.03^{\mathrm{b}}$ & $4.74 \pm 0.04^{\mathrm{a}}$ \\
\hline Xenobiotics Biodegradation and Metabolism & $3.54 \pm 0.09^{\mathrm{ab}}$ & $3.30 \pm 0.03^{\mathrm{d}}$ & $3.47 \pm 0.14^{\mathrm{abc}}$ & $3.57 \pm 0.03^{\mathrm{a}}$ & $2.59 \pm 0.07^{\mathrm{e}}$ \\
\hline
\end{tabular}




\section{Table 5 (on next page)}

Other functional genes from bacteria in the samples. Letters indicate Duncan's pairwise differences among samples from different origins $(P<0.05)$ 
Table 5 Other functional genes from bacteria in the samples. Letters indicate Duncan's pairwise differences among samples from different origins $(\mathrm{P}<0.05)$.

\begin{tabular}{|c|c|c|c|c|c|}
\hline \multirow{3}{*}{ Function } & \multicolumn{5}{|c|}{ Percentage composition in samples } \\
\hline & Xizang & Sichuan & Qinghai & Gansu & Yunnan \\
\hline & $\mathrm{n}=3$ & $\mathrm{n}=3$ & $\mathrm{n}=3$ & $\mathrm{n}=3$ & $\mathrm{n}=3$ \\
\hline Cell Growth and Death & $0.58 \pm 0.02^{\mathrm{c}}$ & $0.44 \pm 0.00^{\mathrm{e}}$ & $0.57 \pm 0.01^{\text {cd }}$ & $0.63 \pm 0.00^{\mathrm{b}}$ & $0.65 \pm 0.00^{\mathrm{a}}$ \\
\hline Cell Motility & $0.62 \pm 0.09^{\mathrm{cd}}$ & $2.28 \pm 0.05^{\mathrm{a}}$ & $1.54 \pm 0.73^{\mathrm{b}}$ & $0.58 \pm 0.04^{\text {cde }}$ & $0.64 \pm 0.01^{\mathrm{c}}$ \\
\hline Transport and Catabolism & $0.17 \pm 0.01^{\mathrm{c}}$ & $0.20 \pm 0.00^{\mathrm{ab}}$ & $0.22 \pm 0.04^{\mathrm{a}}$ & $0.13 \pm 0.01^{\mathrm{cd}}$ & $0.12 \pm 0.00^{\text {de }}$ \\
\hline Membrane Transport & $11.34 \pm 0.38^{\mathrm{d}}$ & $13.51 \pm 0.07^{\mathrm{ab}}$ & $12.28 \pm 0.63^{\mathrm{c}}$ & $11.18 \pm 0.04^{\mathrm{de}}$ & $13.86 \pm 0.22^{\mathrm{a}}$ \\
\hline Signaling Molecules and Interaction & $0.34 \pm 0.00^{\mathrm{ab}}$ & $0.28 \pm 0.00^{\mathrm{d}}$ & $0.27 \pm 0.05^{\mathrm{de}}$ & $0.35 \pm 0.00^{\mathrm{a}}$ & $0.33 \pm 0.00^{\mathrm{abc}}$ \\
\hline Signal Transduction & $1.35 \pm 0.04^{\text {cde }}$ & $2.28 \pm 0.02^{\mathrm{a}}$ & $1.67 \pm 0.25^{\mathrm{b}}$ & $1.36 \pm 0.02^{\mathrm{cd}}$ & $1.53 \pm 0.01^{\mathrm{bc}}$ \\
\hline Folding, Sorting and Degradation & $2.40 \pm 0.06^{\mathrm{bc}}$ & $2.15 \pm 0.00^{\mathrm{d}}$ & $2.24 \pm 0.12^{\mathrm{de}}$ & $2.59 \pm 0.02^{\mathrm{a}}$ & $2.50 \pm 0.02^{\mathrm{ab}}$ \\
\hline Replication and Repair & $8.20 \pm 0.07^{\mathrm{c}}$ & $7.44 \pm 0.08^{\mathrm{e}}$ & $8.14 \pm 0.12^{\text {cd }}$ & $8.56 \pm 0.04^{b}$ & $11.04 \pm 0.18^{\mathrm{a}}$ \\
\hline Transcription & $2.34 \pm 0.05^{\mathrm{d}}$ & $2.63 \pm 0.01^{\mathrm{a}}$ & $2.55 \pm 0.17^{\mathrm{abc}}$ & $2.31 \pm 0.01^{\mathrm{de}}$ & $2.55 \pm 0.03^{\mathrm{ab}}$ \\
\hline Translation & $5.42 \pm 0.07^{\mathrm{bc}}$ & $4.77 \pm 0.06^{\mathrm{e}}$ & $5.26 \pm 0.18^{\mathrm{cd}}$ & $5.55 \pm 0.03^{b}$ & $7.15 \pm 0.12^{\mathrm{a}}$ \\
\hline Cancers & $0.14 \pm 0.01^{\mathrm{c}}$ & $0.11 \pm 0.00 \mathrm{~d}^{\mathrm{e}}$ & $0.12 \pm 0.01^{\mathrm{d}}$ & $0.20 \pm 0.00^{\mathrm{a}}$ & $0.16 \pm 0.00^{b}$ \\
\hline Cardiovascular Diseases & $0.02 \pm 0.00 \mathrm{~b}^{\mathrm{c}}$ & $0.01 \pm 0.00^{\mathrm{de}}$ & $0.02 \pm 0.01^{\mathrm{b}}$ & $0.02 \pm 0.00^{\mathrm{a}}$ & $0.01 \pm 0.00^{\mathrm{d}}$ \\
\hline Immune System Diseases & $0.06 \pm 0.00^{\mathrm{e}}$ & $0.08 \pm 0.00^{\mathrm{bc}}$ & $0.07 \pm 0.00^{\mathrm{bcd}}$ & $0.08 \pm 0.00^{\mathrm{b}}$ & $0.10 \pm 0.00^{\mathrm{a}}$ \\
\hline Infectious Diseases & $0.44 \pm 0.01^{\mathrm{cd}}$ & $0.55 \pm 0.00^{\mathrm{a}}$ & $0.46 \pm 0.02^{b}$ & $0.41 \pm 0.00^{\mathrm{e}}$ & $0.44 \pm 0.00^{c}$ \\
\hline MetabolicDiseases & $0.10 \pm 0.00^{b}$ & $0.09 \pm 0.00^{\mathrm{d}}$ & $0.10 \pm 0.00^{\mathrm{bc}}$ & $0.09 \pm 0.00^{\mathrm{de}}$ & $0.11 \pm 0.00^{\mathrm{a}}$ \\
\hline NeurodegenerativeDiseases & $0.51 \pm 0.05^{\mathrm{ab}}$ & $0.29 \pm 0.01^{\mathrm{cd}}$ & $0.34 \pm 0.11^{c}$ & $0.61 \pm 0.01^{\mathrm{a}}$ & $0.28 \pm 0.03^{\text {cde }}$ \\
\hline Circulatory System & $0.09 \pm 0.01^{\mathrm{ab}}$ & $0.04 \pm 0.00^{\text {cde }}$ & $0.05 \pm 0.03^{\mathrm{d}}$ & $0.12 \pm 0.00^{\mathrm{a}}$ & $0.05 \pm 0.01^{\mathrm{cd}}$ \\
\hline Digestive System & $0.04 \pm 0.00^{\mathrm{a}}$ & $0.02 \pm 0.00^{\mathrm{bcd}}$ & $0.03 \pm 0.01^{b}$ & $0.03 \pm 0.00^{\mathrm{bc}}$ & $0.01 \pm 0.00^{\mathrm{e}}$ \\
\hline Endocrine System & $0.14 \pm 0.02^{\mathrm{d}}$ & $0.21 \pm 0.00^{\mathrm{ab}}$ & $0.22 \pm 0.07^{\mathrm{a}}$ & $0.08 \pm 0.01^{\mathrm{de}}$ & $0.10 \pm 0.00^{\text {cd }}$ \\
\hline Environmental Adaptation & $0.12 \pm 0.00^{\mathrm{bcd}}$ & $0.10 \pm 0.00^{\mathrm{e}}$ & $0.12 \pm 0.00^{\mathrm{bc}}$ & $0.12 \pm 0.00^{\mathrm{b}}$ & $0.16 \pm 0.00^{\mathrm{a}}$ \\
\hline Excretory System & $0.00 \pm 0.00^{\mathrm{de}}$ & $0.02 \pm 0.00^{\mathrm{abc}}$ & $0.02 \pm 0.01^{\mathrm{a}}$ & $0.02 \pm 0.00^{\mathrm{ab}}$ & $0.01 \pm 0.00^{\mathrm{abcd}}$ \\
\hline Immune System & $0.06 \pm 0.00^{\mathrm{a}}$ & $0.04 \pm 0.00^{\text {cd }}$ & $0.04 \pm 0.02^{c}$ & $0.06 \pm 0.00^{\mathrm{ab}}$ & $0.02 \pm 0.00^{\mathrm{e}}$ \\
\hline Nervous System & $0.05 \pm 0.00^{\mathrm{e}}$ & $0.10 \pm 0.00^{\mathrm{a}}$ & $0.06 \pm 0.01^{\mathrm{bc}}$ & $0.06 \pm 0.00^{\mathrm{cd}}$ & $0.07 \pm 0.00^{\mathrm{b}}$ \\
\hline Unclassified & $15.43 \pm 0.05^{\mathrm{ab}}$ & $15.61 \pm 0.00^{\mathrm{a}}$ & $14.48 \pm 0.71^{\mathrm{cd}}$ & $14.57 \pm 0.06^{\mathrm{c}}$ & $13.74 \pm 0.08^{\mathrm{e}}$ \\
\hline
\end{tabular}

